\title{
Extrudable Reactive Powder Concretes Hydration, shrinkage and transfer properties
}

\author{
Pierre Mounanga $^{1}$ - Khalid Cherkaoui $^{1,2}$ - Abdelhafid Khelidj $^{1}$ \\ - Mireille Courtial $^{2,3}$ - Marie-Noëlle de Noirfontaine ${ }^{2}$ \\ Frédéric Dunstetter ${ }^{2}$
}

${ }^{1}$ LUNAM Université, Université de Nantes - IUT Saint-Nazaire, GeM, CNRS UMR 6183, Institut de Recherche en Génie Civil et Mécanique, France

${ }^{2}$ Laboratoire des Solides Irradiés, CNRS UMR 7642 - CEA-Ecole Polytechnique, Ecole Polytechnique 91128 Palaiseau Cedex, France

${ }^{3}$ IUT de Béthune, 1230 rue de l'Université, 62400 Béthune Cedex, France

[pierre.mounanga,khalid.cherkaoui,abdelhafid.khelidj]@univ-nantes.fr

[mireille.courtial,marie-noelle.de-noirfontaine]@polytechnique.edu

dunstet@poly.polytechnique.fr

\begin{abstract}
RÉSUMÉ. Le comportement de cinq bétons de poudres réactives (BPR), dont quatre présentent des propriétés d'extrudabilité, a été étudié depuis les premières minutes après leur fabrication jusqu'à plus de 90 jours de maturation. La force d'extrusion, la cinétique d'hydratation, le développement du retrait endogène libre au jeune âge, les propriétés mécaniques et les paramètres de durabilité ont été mesurés. L'analyse des performances a montré l'intérêt d'une substitution partielle de la fumée de silice par du quartz broyé sur les propriétés des BPR. L'analyse coût/performances a mis en évidence que le principal avantage de l'utilisation des BPR réside dans leur potentiel de durabilité, 10 à 100 plus élevé que celui de bétons ordinaires ou à hautes performances, selon la propriété considérée.

ABSTRACT. The behavior of five reactive powder concretes (RPC), with four of them being extrudable, has been studied since the first minutes up to more than 90 days. The extrusion force, hydration rate, free autogenous shrinkage at early age, mechanical properties and durability parameters were measured. The performance analysis showed the benefits of a partial substitution of silica fume with crushed quartz on the RPC properties. The cost/performances analysis highlighted that the main advantage of using RPC lies in their potential of durability, which is 10 to 100 times higher than that of ordinary or highperformance concretes, according to the property considered.
\end{abstract}

MOTS-CLÉS: Béton de poudres réactives, extrusion, hydratation, retrait, durabilité

KEYWORDS: Reactive powder concrete, extrusion, hydration, shrinkage, durability 


\section{Introduction}

Reactive Powder Concretes (RPC) constitute a particular type of cementitious materials developed in the early 1990s (Richard et al., 1994, 1995; Aïtcin 2000) and characterized by ultra-high mechanical performances and very low porosity. After a specific heat treatment, their compressive strength lies between 200 and $800 \mathrm{MPa}$. RPC are mainly used in civil engineering projects as bridges or airports (Aïtcin 2000), or as repair materials for concrete structures (Denarié et al., 2006; Lee et al., 2007). Also, the low porosity of RPC gives excellent durability and transport properties, suitable for the storage of nuclear waste (Matte et al., 1999). Their proportioning principles are based on the optimization of the microstructure (Bonneau et al., 2000), by enhancing the granular packing and minimizing the interparticle porosity. This is obtained by combining fines mineral particles (Portland cement, crushed filler, silica fume, fine sand) in the range of 0.02 to 600 microns, with very low water-to-cement ratio and high amount of high-range water-reducing superplasticizer (Richard et al., 1994).

This cocktail of constituents, with very different physico-chemical properties and particle size distributions, results in a particularly dense skeleton with a wide range of rheological behaviors, from very viscous (Kuder et al., 2007a) to highly flowable (Liu et al., 2008). Nevertheless, the mix design of RPC remains a complex process because of the sensitivity of the mixture properties to even small changes in the constituent dosages. Another major obstacle to the wide use of these materials is their high cost compared to that of high or very high-performance concretes (Blais et al., 1999).

The use of industrial making processes could enable to overcome these issues by ensuring both compliance with the mix design throughout the production chain and high production rates. From this point of view, the extrusion process seems to meet such requirements: it is an advanced processing technique already applied to a wide range of materials (food, polymer, clay and metal). In the field of cement-based materials, extrusion has proved to be an efficient technique, particularly adapted for the production of prefabricated elements with very high mechanical performances (Qian et al., 2003; Kuder et al., 2007b; Perrot et al., 2007).

In this context, the present study is devoted to the development of extrudable RPC (ERPC), especially designed for the manufacture of tubular elements adapted to chemically aggressive environments. To this end, various RPC were prepared with varying dosages of polycarboxylate superplasticizer, silica fume and crushed quartz to obtain extrudable mixtures. Alongside their microstructural analysis by Xray diffraction and scanning electron microscopy (Courtial et al., 2011), the materials were characterized at fresh state (extrudability), at early age (hydration rate and autogenous shrinkage) and at longer term (mechanical strength, porosity and mass transfer parameters). The article proposes a cross-analysis of the ERPC properties measured before extrusion, and a comparative cost/benefits ratio analysis including other types of concretes. 


\section{Experimental procedures}

\subsection{Materials and mixtures}

The ERPC studied were prepared with Portland cement (CEM I 52.5N, produced by Lafarge in Le Havre's plant), silica fume (commercialized by Condensil), crushed quartz powder (Millisil C500, Sibelco), siliceous sand (CV32, Sibelco), superplasticizer, noted SP (Cimfluid 2002, Axim) and water. The cement contained $3.30 \%$ of gypsum and its Bogue composition was $67.50 \%$ of $\mathrm{C}_{3} \mathrm{~S}, 10.70 \%$ of $\mathrm{C}_{2} \mathrm{~S}, 2.64 \%$ of $\mathrm{C}_{3} \mathrm{~A}, 12.80 \%$ of $\mathrm{C}_{4} \mathrm{AF}$. The chemical composition of the solid components of ERPC is provided in Table 1. Their density and fineness are given in Table 2. The SP used was a modified-polycarboxylate high-range water-reducing superplasticizer in liquid form with $35 \%$ of dry matter. The dosages of SP, indicated in Table 3, correspond to the mass ratio between the SP dry matter and the cement content.

The ERPC were manufactured by mixing the solid compounds with tap water in a 20 -L mixer. The water-to-cement (W/C) ratio was equal to 0.16 for all the ERPC. The same mixing procedure, schematized in Figure 1, was rigorously applied for each batch. The total time of mixing was $25 \mathrm{~min}$. The composition of the five ERPC mixtures investigated is given in Table 3 .

It is important to note that all the tests presented in the following sections were performed on non-extruded ERPC samples.

Table 1. Chemical composition (mass percentage) of the solid components of ERPC

\begin{tabular}{|c|c|c|c|c|}
\hline Constituents & Portland cement & Silica fume & Sand & Crushed quartz \\
\hline $\mathrm{CaO}$ & 64.58 & - & $<0.023$ & $<300 \mathrm{ppm}$ \\
\hline $\mathrm{SiO}_{2}$ & 21.39 & 93.50 & $>98.7$ & $>98.9$ \\
\hline $\mathrm{Al}_{2} \mathrm{O}_{3}$ & 3.66 & \multirow{4}{*}{6.10} & $<0.6$ & $<8000 \mathrm{ppm}$ \\
\hline $\mathrm{Fe}_{2} \mathrm{O}_{3}$ & 4.25 & & $<0.045$ & $<800 \mathrm{ppm}$ \\
\hline $\mathrm{MgO}$ & 0.96 & & - & - \\
\hline $\mathrm{M}_{2} \mathrm{O}$ & 0.28 & \multirow{4}{*}{6} & $<0.460$ & $<6000 \mathrm{ppm}$ \\
\hline $\mathrm{SO}_{3}$ & 2.63 & & - & - \\
\hline $\mathrm{Na}_{2} \mathrm{O}$ & 0.10 & 0.15 & - & - \\
\hline
\end{tabular}

Table 2. Fineness and density of the solid components of ERPC

\begin{tabular}{|l|c|c|c|c|}
\hline Materials & $\begin{array}{c}\text { Portlan } \\
\mathrm{d} \\
\text { cement }\end{array}$ & $\begin{array}{c}\text { Silica } \\
\text { fume }\end{array}$ & $\begin{array}{c}\text { Crushed } \\
\text { quartz }\end{array}$ & Sand \\
\hline Specific surface area $\left(\mathrm{m}^{2} / \mathrm{kg}\right)$ & 382 & 14000 & 1030 & 12.6 \\
\hline
\end{tabular}




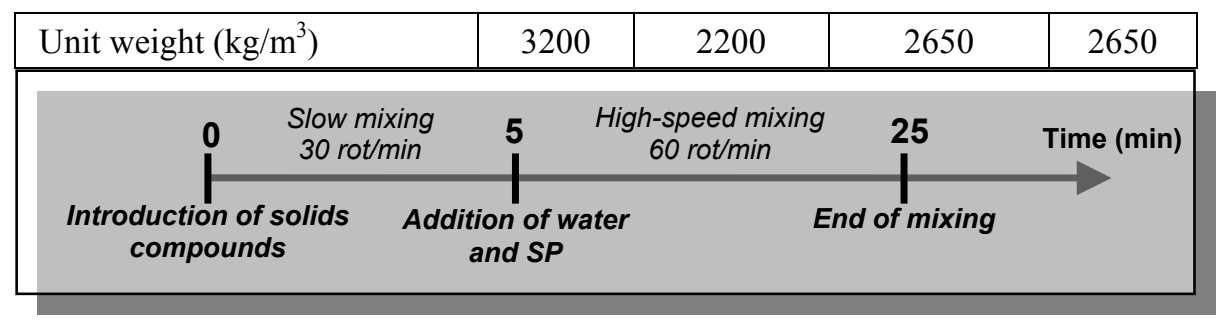

Figure 1. Mixing procedure of ERPC

Table 3. Composition of ERPC (mass proportion)

\begin{tabular}{|l|c|c|c|c|c|c|}
\hline Mixtures & $\begin{array}{c}\text { Portland } \\
\text { cement }\end{array}$ & Sand & Silica fume & $\begin{array}{c}\text { Crushed } \\
\text { quartz }\end{array}$ & SP* & Water \\
\hline ERPC_1 & 1 & 1.1 & 0.25 & 0 & $0.5 \%$ & 0.16 \\
\hline ERPC_2 & 1 & 1.1 & 0.25 & 0 & $1.0 \%$ & 0.16 \\
\hline RPC_3 & 1 & 1.1 & 0.25 & 0 & $1.8 \%$ & 0.16 \\
\hline ERPC_4 & 1 & 1.1 & $0.25 \times 3 / 4$ & $0.25 \times 1 / 4$ & $1.8 \%$ & 0.16 \\
\hline ERPC_5 & 1 & 1.1 & $0.25 \times 3 / 4$ & $0.25 \times 1 / 4$ & $2.0 \%$ & 0.16 \\
\hline
\end{tabular}

*: Superplasticizer

\subsection{Test procedures}

In order to control the test conditions, the experimental devices were placed in a temperature-controlled room at $20 \pm 1^{\circ} \mathrm{C}$.

\subsubsection{Extrusion tests}

The extrusion tests were carried out with a ram extruder (home-made device) placed on a $50-\mathrm{kN}$ compression test machine. The diameter and the length of the circular die were $1.2 \mathrm{~cm}$ and $3 \mathrm{~cm}$, respectively. The experimental system is presented in Figure 2. Before each test, the sample was put under vacuum for 5 minutes, to de-aerate the material without losing significant amounts of water by evaporation. The barrel of the extruder was then completely filled with freshlymixed material.

A pre-compression phase enabled to obtain a similar initial state of the various ERPC before extrusion. Then the extrusion started, and the ram drove down at a selected constant speed. During the test, the force exerted by the piston and its displacement were recorded. Different extrusion rates were applied to measure the effect of this parameter on the extrudability of the RPC. 

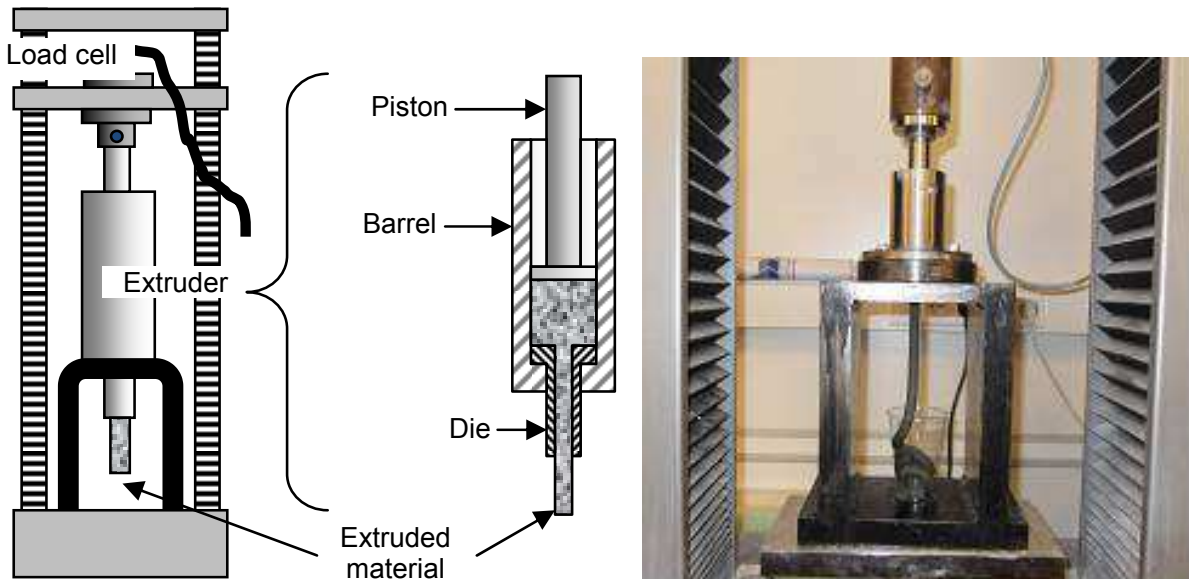

Figure 2. Extrusion test device

\subsubsection{Hydration rate}

Isothermal microcalorimetry (TAM Air apparatus) was used to compare the early-age hydration rate of the different ERPC. For each mix, two samples of about $4 \mathrm{~g}$ were taken from the same batch and placed into flasks immediately after mixing. The flasks were then loaded in the apparatus and the heat flow produced by the hydration reactions was recorded during the first six days at $20^{\circ} \mathrm{C}$. The average curves from two samples of each mix were used for analysis.

\subsubsection{Autogenous strain}

Early-age autogenous strains of ERPC in free conditions were measured with a specific experimental system presented in previous articles (Bouasker et al., 2008; Mounanga et al., 2011a). It was a horizontal linear experimental system (Figure 3) inspired by the works of Laplante and Boulay (Laplante et al., 1994) and Jensen and Hansen (Jensen et al., 1995). The fresh material was cast in a molded, tight and very flexible PVC membrane and immersed in a thermostated water bath at $20 \pm 1^{\circ} \mathrm{C}$. Waterproof contactless sensors were used to measure the longitudinal specimen displacements, which were automatically recorded by a data logging system connected to the sensors. This method made it possible to follow the deformations of the sample from its very early age. 


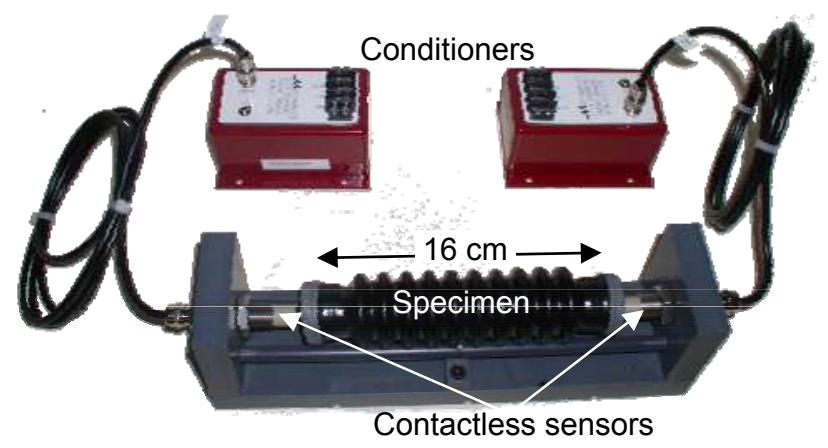

Figure 3. Free linear autogenous shrinkage test device

\subsubsection{Mechanical properties}

The 28-day mechanical properties of ERPC were determined on $40 \times 40 \times 16$-mm prismatic specimens kept in autogenous conditions at $20 \pm 1^{\circ} \mathrm{C}$ until testing. The dynamic Young's modulus $E_{d y n}$ was measured via impulse excitation tests with a Grindosonic ${ }^{\circledR}$ device. The mean value of three readings of the flexural resonant frequencies was adopted to determine the dynamic Young's modulus (Spinner et al., 1961). The flexural strength $R_{F}$ was obtained from the results of three-point flexural tests and the compressive strength $R_{C}$ was determined on both parts of each specimen used for flexural tests. Each test was repeated at least three times and the results were used to calculate an average value of the mechanical performances.

\subsubsection{Porosity and transfer properties}

The gas permeability $K_{V}$, the water-accessible porosity $n$ and the chloride diffusion coefficient $D_{e}$ were measured on ERPC discs of $11-\mathrm{cm}$ diameter and $5-\mathrm{cm}$ thickness, aged of more than 90 days, oven-dried at $80^{\circ} \mathrm{C}$ for several weeks, until constant mass $( \pm 0.01 \mathrm{~g})$ and cooled during $48 \mathrm{~h}$ in a desiccator at $20 \pm 1^{\circ} \mathrm{C}$.

The intrinsic gas permeability was determined using a Cembureau permeameter with nitrogen as the neutral percolating gas. The test method consisted in applying various differential pressures to the concrete disc and in measuring the steady flow of gas passing through the specimen (Picandet et al., 2001). The intrinsic coefficient of permeability, as defined by Klinkenberg (Klinkenberg 1941), was then calculated assuming a laminar flow, compressible fluid and steady state of flow in the specimens.

The volume percentage of water-accessible porosity in ERPC specimens was estimated by successively measuring the mass of the ERPC discs in dry state, in saturated state and in hydrostatic conditions (saturated and submerged in water), according to the procedure proposed by the AFPC-AFREM (AFPC-AFREM 1997). 
After the gas permeability and porosity tests, each ERPC disc was placed between two chambers containing solutions of $\mathrm{NaOH}(0.025 \mathrm{~mol} / \mathrm{L})$ and $\mathrm{KOH}$ $(0.083 \mathrm{~mol} / \mathrm{L}) . \mathrm{NaCl}(0.513 \mathrm{~mol} / \mathrm{L})$ was added in the upstream solution and a $12-\mathrm{V}$ potential difference was applied between the two parallel sides of the concrete sample. The chloride concentration in the downstream tank was determined by means of potentiometric titration with a Metrohm SA CH- 9101 Herisau automatic titrator, with 0.05 molar silver nitrate $\left(\mathrm{AgNO}_{3}\right)$ titrant (Djerbi et al., 2008).

\section{Results and discussion}

\subsection{Extrudability}

The extrusion tests were performed at various ram speeds $(10,20$ and 40 $\mathrm{mm} / \mathrm{min}$ ) on the five RPC. Figure 4 presents an extrusion test and the "forcedisplacement" curves obtained on ERPC_1 and ERPC_2. At the die exit of the extrusion system, the self-supporting material left in a continuous manner and without cracks. In addition, the ERPC did not exhibit visible phase migration or separation of phases after extrusion. These observations prove the extrusion capacity of the ERPC. The "force-displacement" curves recorded during the extrusion tests could be segmented into three main parts (Aouadja et al., 1997; Perrot 2006):

- The first part of the curves (Zone 1) was relative to a phase of non stationary flow due to the placing and the settling of the material into the barrel. The duration of this phase was particularly influenced by changes in the SP dosage: considering the other mix parameters as constant, we observed that an increase in the dosage of superplasticizer caused an extension of the Zone 1 (Figures 4.A and 4.B).

- The second part (Zone 2) corresponded to a zone of steady flow, showing the establishment of a permanent flow of the ERPC for a relatively constant extrusion force. At this moment, the material reached its plasticity threshold (Perrot 2006). The extrusion force, whose intensity corresponded to the horizontal stage of the curves, increased when the ram speed increased and decreased as the dosage of superplasticizer increased, for given dosages in solid constituents,

- The third phase (Zone 3) indicated the end of the test. It appeared when the piston approached the entry die. It was characterized by rapid changes in force for a small displacement of the piston. This phase corresponded to the compression of the dead zone of the extruder and the complete emptying of the die. The maximum capacity of the extruder system was then reached and the extrusion was stopped.

During these tests, only RPC_3 appeared as not extrudable because too fluid. Besides, the introduction of crushed quartz, coarser than silica fume, in the mix composition enabled to increase the viscosity of the mixture and to obtain extrudable concretes, even for high dosages of SP (ERPC_4 and ERPC_5). This result shows that the optimization of both dosages of crushed quartz and SP could allow to minimize the force needed for the extrusion of ERPC. 

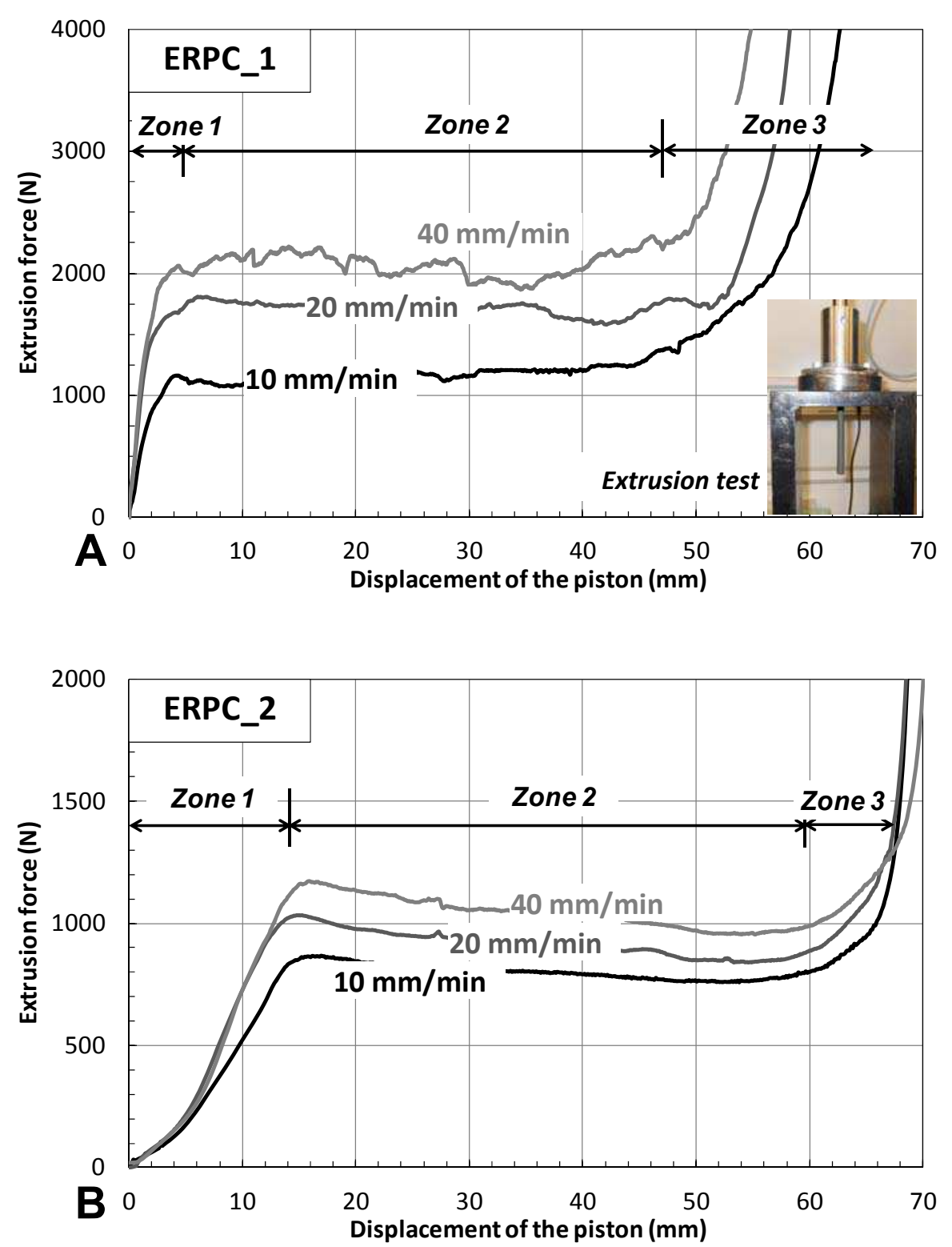

Figure 4. Extrusion test results of ERPC_1 (A) and ERPC_2 (B) at three different ram speeds 


\subsection{Hydration rate}

Figure 5 presents the evolution of the heat flow of hydration monitored by isothermal microcalorimetry. Each curve is characterized by a dormant period with a very low evolution of the heat flow, followed by a peak marking a period of intense chemical activity. This early-age chemical activity of ERPC may be mainly attributed to Portland cement hydration, since it was shown that, at $20^{\circ} \mathrm{C}$, the pozzolanic reactions of silica fume remained weak during several days (Mansoutre et al., 1996; Loukili et al., 1999), and even nil for crushed quartz (Zanni et al., 1996). The peak of heat flow could therefore be associated with the hydration of $\mathrm{C}_{3} \mathrm{~S}$, the major phase of Portland cement (Taylor 1990; Odler 1998). It occurred at 25.2, 40.7, 59.7, 55.4 and $58.6 \mathrm{~h}$ for ERPC_1, ERPC_2, RPC_3, ERPC_4 and ERPC 5 mixtures, respectively. The appearance of this peak was considerably delayed when comparing with the hydration rate of an ordinary Portland cement mortar, whose hydration peak usually developed within the first $12 \mathrm{~h}$ of hydration (Mounanga et al., 2011b). This delay was caused by the high dosage of SP in ERPC, which induced an extension of the dormant period of the hydration reactions. This slowing down was particularly high for RPC 3 and also resulted in a significant decrease of the hydration peak intensity, as shown in Figure 5. This secondary effect of SP on cement hydration is well-known and explained by the adsorption of the polymers on cement grains, and also by possible reactions of the $\mathrm{Ca}^{2+}$ ions with polymer anions (Mollah et al., 2000), which generate a global retardation of hydration.

The presence of crushed quartz enabled to partially limit the retardation effect of SP on hydration rate: indeed, the hydration peak of the ERPC_4-curve developed about $4 \mathrm{~h}$ before that of the RPC 3 curve, for identical SP dosage. The peak magnitude was also higher for ERPC_4, as compared with RPC_3, indicating a greater chemical activity at early age. This positive influence of crushed quartz on the advancement of reactions may be caused by an effect of nucleation site on the development of hydrates: Indeed, Cyr et al. (Cyr et al., 2006) highlighted that the presence of very fine particles (with specific surface area higher than $100 \mathrm{~m}^{2} / \mathrm{kg}$ ) could activate the cement hydration by heterogeneous nucleation. This physical process is related to the nucleation of hydrates on foreign mineral particles and causes an acceleration of the early-age cement hydration and setting.

Several studies have shown that silica fume also has the ability to accelerate early-age cement reactions by nucleation and growth site effect (Cheng et al., 1985; Lilkov et al., 1997; Zelić et al., 2000, for example). Some of these studies revealed that this accelerating effect depended on both the initial water content and the dosage of silica fume (Langan et al., 2002; Kadri et al., 2009). It seems that, for the ERPC investigated and the powder dosage considered here, crushed quartz was more efficient than silica fume in increasing early-age cement hydration rate. 


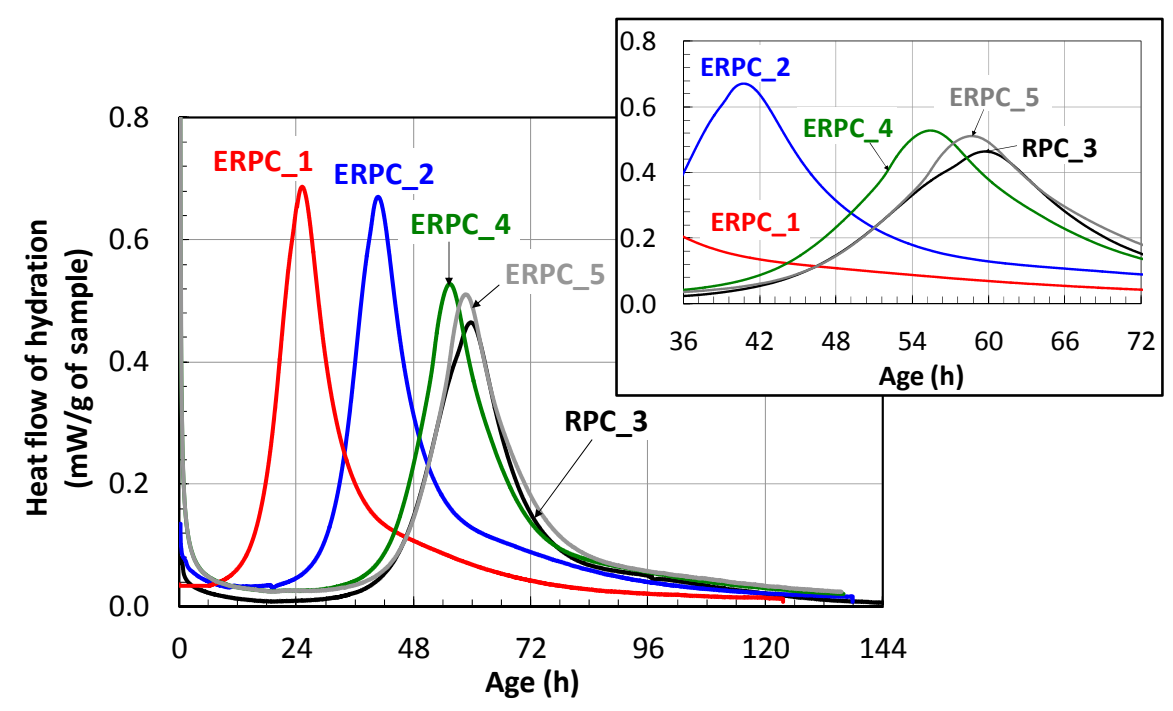

Figure 5. Isothermal calorimetry curves of the ERPC

\subsection{Early-age autogenous shrinkage}

Figure 6 shows the results of free linear autogenous shrinkage of ERPC at $20^{\circ} \mathrm{C}$. As the deformations were monitored from the very first minutes after mixing, the autogenous strain measured was a combination of chemical shrinkage and selfdesiccation shrinkage. Chemical shrinkage, also called Le Chatelier's contraction, develops before the setting of the matrix: it mainly corresponds to the dissolution of clinker minerals, hydration of anhydrite and precipitation of ettringite (Beltzung et al., 2000), and to the negative balance between the absolute density of hydrates and those of the binder and water (Powers et al., 1948; Mounanga et al., 2004). The setting and the progressive water desaturation of the porous network leads to a second type of deformation, called self-desiccation shrinkage. Self-desiccation is directly linked to the initial water content of the cement-based material, a lower water-to-binder ratio giving higher self-desiccation shrinkage (Baroghel-Bouny et al., 2006). The transition between chemical shrinkage and self-desiccation shrinkage is generally marked by the flattening of the autogenous shrinkage curve (Justnes et al., 1996).

In our case, considering identical dosages of cement and water and low reactivity of the supplementary cementing materials at early-age, the gap between the autogenous shrinkage curves of the different ERPC may be due to both the varying SP content and the partial substitution of silica fume with crushed quartz. The hydration retardation induced by the SP, highlighted in the previous section, led to a delay of setting and an extension of the deformation phase dominated by chemical shrinkage. The development of the chemical shrinkage of the ERPC was particularly high during the first hours, while the main peak of hydration has not yet 
appeared (Figure 5). This discrepancy between the relatively low heat release of the ERPC and the significant very early-age volume changes was closely related to the dosage in SP of the ERPC: indeed, RPC_3 (SP dosage $=1.8 \%$ ) exhibited higher autogenous shrinkage values than ERPC 2 (SP dosage $=1.0 \%)$, whose autogenous shrinkage was higher than that of ERPC_1 (SP dosage $=0.5 \%)$. The flattening of the curves, which indicates the transition from chemical to self-desiccation shrinkage, also appeared later when the SP content increased. All other mix parameters being kept constant, the partial substitution of silica fume with crushed quartz induced a decrease of the autogenous shrinkage of ERPC_4, when compared to that of RPC_3 (Figure 6). This positive effect of crushed quartz on early-age autogenous strain can be linked to its acceleration effect on cement hydration rate (see section 3.2): it may be supposed that the presence of crushed quartz attenuated the SP retardation effect on the setting time of ERPC. Therefore, the material hardened more rapidly and resisted more efficiently to the strain imposed by Le Chatelier's contraction and the water desaturation of the porous network. Crushed quartz probably also led to a better particle packing and, consequently, to a reorganization of the porous network of the cementitious matrix: as the pore distribution is one of the major parameters controlling the evolution of selfdesiccation (Jiang et al., 2005), this effect of crushed quartz on the mitigation of early-age ERPC autogenous shrinkage, should be investigated more deeply. A third complementary explanation to the lower autogenous strain of ERPC_4 was the higher Young's modulus value of this mixture (Table 4): submitted to an identical internal capillary tension, it will shrink less than the other ERPC.

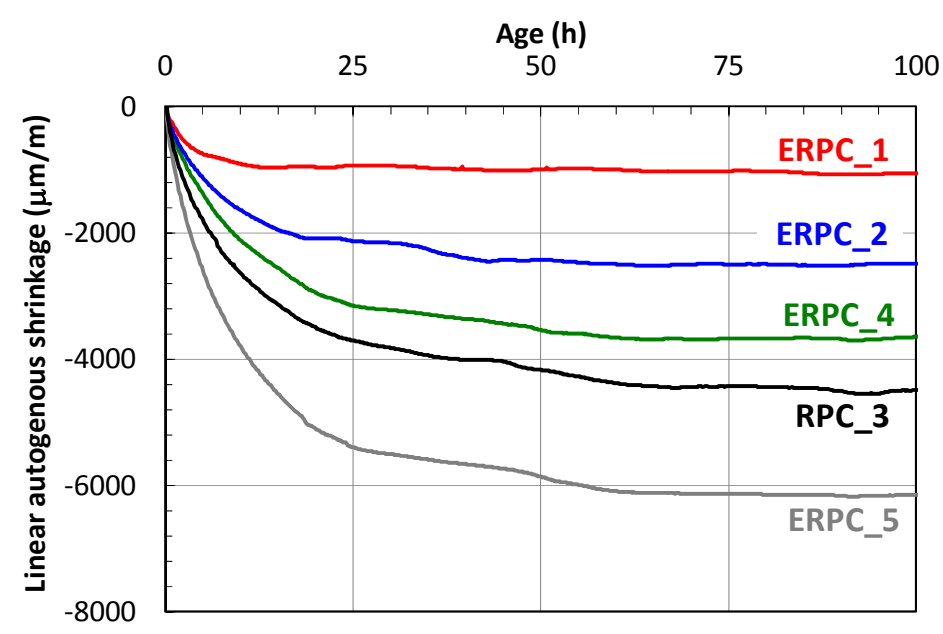

Figure 6. Early-age linear autogenous shrinkage of the ERPC 


\subsection{Mechanical and transfer properties}

Table 4 provides the 28-day mechanical performances of ERPC, ordinary and high-performance concretes, for comparison. The ERPC compressive strength values were in the same range than those given by Richard and Cheyrezy (Richard et al., 1995), for a RPC200 without fibers, cured at $20^{\circ} \mathrm{C}$, and more recently by Yazici (Yazici 2007).

The increase of SP content resulted in a significant decrease of compressive strength and a simultaneous increase of Young's modulus. Indeed, the addition of SP generates a more homogeneous microstructure, promoting a better distribution of hydrates around the sand grains. This would prevent the phenomena of rigidification and locking created by contacts between solid grains. The SP may also play the role of a lubricant around some solid particles that are not in contact with the hydrates. The effect of SP content was less significant on flexural strength.

The partial replacement of silica fume with crushed quartz appeared to significantly improve the mechanical properties of ERPC: it led to an increase of $25 \%$ of the compressive strength, $20 \%$ of the flexural strength and $16 \%$ of the dynamic Young's modulus, for a constant SP content (Table 4). This improvement of mechanical performances could be explained by a better hydration of cement in presence of crushed quartz, as already observed on microcalorimetry curves (Figure 4) and by a better granular packing of the ERPC in presence of crushed quartz, which presents a particle size distribution intermediate between the cement and silica fume used (Cherkaoui et al., 2010). Indeed, the optimization of the particle packing is the main way to obtain denser cement-based matrices and therefore greater mechanical performances (Richard et al., 1995; Scrivener et al., 2008)

The water-accessible porosity, the gas permeability and the chloride diffusion coefficient measured on ERPC specimens aged of more than 90 days are presented in Figures 7.a, 7.b and 7.c, respectively, and compared with bibliographical data on ordinary and high-performance concretes (Djerbi 2007). Because of the very low porosity of the ERPC, the measurement of their mass transfer properties was not an easy task. The gas permeability of the ERPC_4 and ERPC_5 mixes were too low to be detectable with the Cembureau permeameter. Moreover, the chloride migration test results highlighted the difficulties in saturating the ERPC porosity with conventional procedures (AFPC-AFREM 1997). The possible hydration of anhydrous cement, which is present in large proportion in RPC, and the potential interactions between cement and chlorides further complicated the result analysis. As expected, the water-accessible porosity was very low (Figure 7.a). The values obtained were close to those presented in previous studies: for example, Resplendino and Petitjean indicated water-accessible porosity values of RPC between 1.5 and 5\% (Resplendino et al., 2003). The absolute differences recorded between the porosity of the five ERPC were not high enough to conclude on a particular effect of SP or crushed quartz content. The gas permeability values of the 
ERPC 1, ERPC 2 and RPC 3 specimens were $3.75 \times 10^{-19} \mathrm{~m}^{2}, 1.62 \times 10^{-19} \mathrm{~m}^{2}$ and $2.56 \times 10^{-19} \mathrm{~m}^{2}$, respectively. The chloride diffusion coefficients of ERPC lay between 0.88 and $1.38 \times 10^{-13} \mathrm{~m}^{2} / \mathrm{s}$. These results could be compared to those presented by Resplendino and Petitjean, who gave an oxygen permeability value lower than $10^{-19} \mathrm{~m}^{2}$ and a chloride-ion diffusion factor equal to $2 \times 10^{-14} \mathrm{~m}^{2} / \mathrm{s}$ for an ultra-high performance concrete (Resplendino et al., 2003).

Table 4. 28-day mechanical properties of ERPC. Comparison with an ordinary concrete (OC) and a high-performance concrete (HPC)

\begin{tabular}{|c|c|c|c|c|c|}
\hline Concretes & $\mathrm{W} / \mathrm{C}$ ratio & $E_{d y n}(\mathrm{GPa})$ & $R_{C}(\mathrm{MPa})$ & $R_{F}(\mathrm{MPa})$ & References \\
\hline $\mathrm{OC}$ & 0.49 & 42.0 & 46 & - & Dierbi 2007 \\
\hline $\mathrm{HPC}$ & 0.38 & 46.0 & 83 & - & 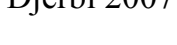 \\
\hline ERPC 1 & \multirow{5}{*}{0.16} & 54.0 & 155 & 19.2 & \multirow{5}{*}{$\begin{array}{c}\text { Present } \\
\text { study }\end{array}$} \\
\hline ERPC_2 & & 59.1 & 150 & 18.6 & \\
\hline RPC_3 & & 60.0 & 140 & 18.6 & \\
\hline ERPC_4 & & 69.4 & 175 & 22.3 & \\
\hline ERPC_5 & & 65.3 & 170 & 20.6 & \\
\hline
\end{tabular}

\section{Comparative cost/benefits analysis}

The composition of RPC, rich in cement, silica fume and superplasticizer, makes them much more expensive than conventional concretes. Indeed, for the ERPC investigated, the dosages of cement, silica fume and superplasticizer range between 962 and $976 \mathrm{~kg} / \mathrm{m}^{3}, 183$ and $242 \mathrm{~kg} / \mathrm{m}^{3}$ and 13 and $56 \mathrm{~L} / \mathrm{m}^{3}$, respectively. The particularly high cost of RPC is one of the main obstacles to a wider use of these concretes, but this aspect is generally not addressed in the articles dealing with RPC. In 1999, Blais and Couture noted that, because of its cost, RPC will not replace conventional concrete where the ordinary concrete can economically meet performance criteria. RPC should rather be seen as a competitor with steel. Blais and Couture also underlined that the cost of RPC dropped one-third between 1997 (the year of the completion of the Sherbrooke pedestrian/bikeway bridge, the world's first major structure to be built with RPC) and 1999. When the Sherbrooke Footbridge was built, the cost of a 200-MPa RPC could be estimated at nearly $\$$ $1,000 \mathrm{US} / \mathrm{m}^{3}$ (Aïtcin 2003), about $870 € / \mathrm{m}^{3}$. In 2003, Aitcin indicated that the same RPC could be made for $\$ 750 \mathrm{US} / \mathrm{m}^{3}\left(650 € / \mathrm{m}^{3}\right)$ and in the near future, it should be possible to produce it for $\$ 600$ to $\$ 650 \mathrm{US} / \mathrm{m}^{3}\left(520\right.$ to $\left.570 € / \mathrm{m}^{3}\right)$. Aitcin also analyzed that even at $\$ 1,000 \mathrm{US} / \mathrm{m}^{3}$, that is to say $\$ 400 \mathrm{US} / \mathrm{ton}(350 € /$ ton), for specific applications where durability and compressive strength were key factors, RPC could compete with structure steel that cost $\$ 1200$ to $\$ 1500 \mathrm{US} / \mathrm{t}$ (1,040 to $1,300 € /$ ton in 2003). 

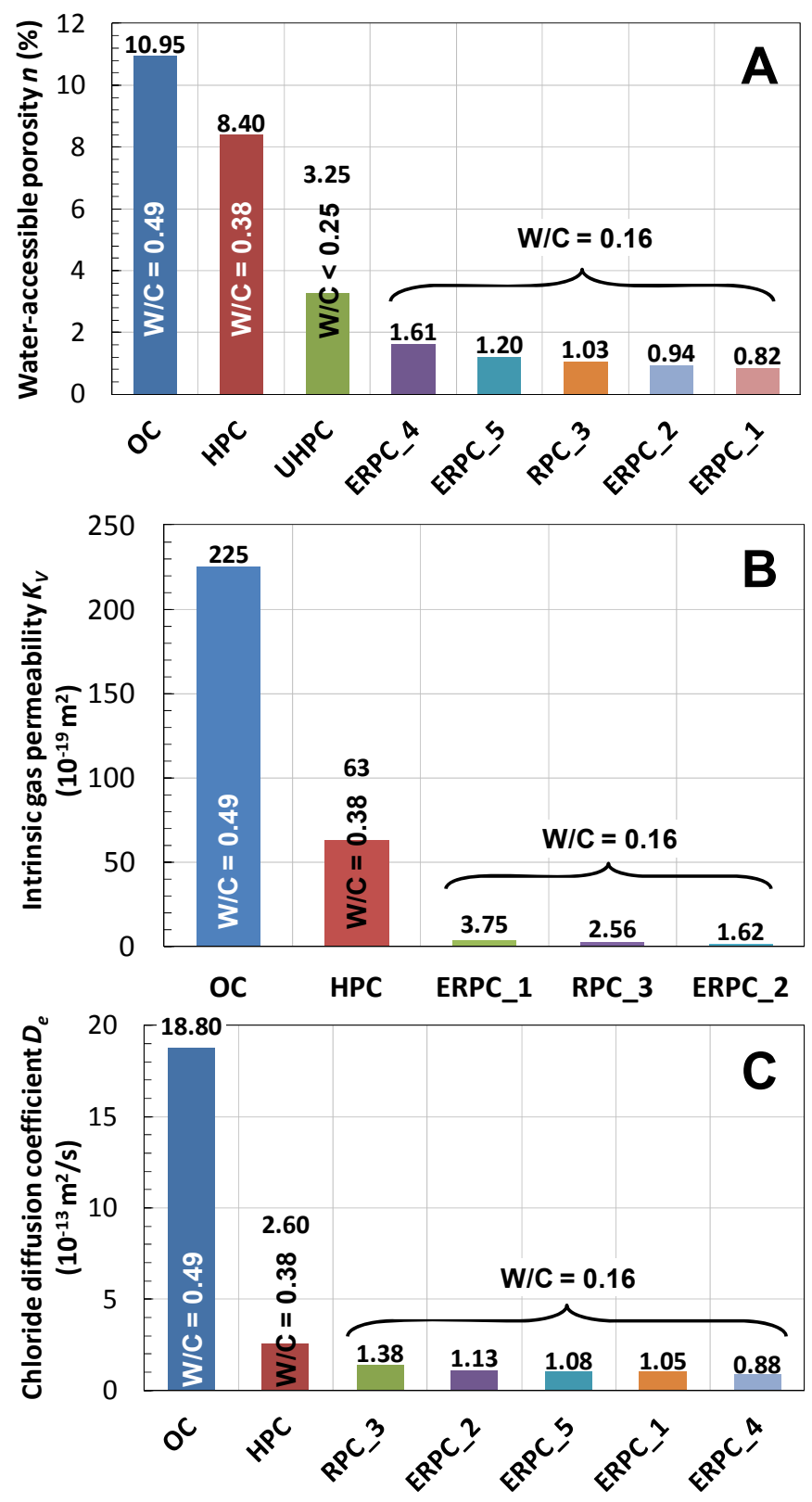

Figure 7. Mass transfer properties of ERPC measured after 90 days of hydration. A: Water-accessible porosity; B: Intrinsic gas permeability; $C$ : Chloride diffusion coefficient. Comparison with an ordinary concrete (OC), a high-performance concrete (HPC) (Djerbi 2007) 
To complete this analysis, the last part of the article is devoted to an estimation of the cost of the ERPC and a comparison of their cost/benefits ratio with those of an ordinary concrete (OC) and a high-performance concrete (HPC) whose properties were taken from the literature (Djerbi 2007). It is worth noting that the approach proposed is only estimative, since the concrete cost and the cost/benefits ratios do not only depend on the cost of the concrete constituents but also on the manufacture process of concrete.

The average costs of each component of concrete are recapitulated in Table 5. The most expensive constituents are the SP and the silica fume. For the latter, the cost is very dependent on the quality and the treatment applied to the material: it can vary from $500 € /$ ton for the grey silica fume to $2,000 € /$ ton for the white silica fume. These data were used to estimate the cost of the ERPC investigated. The high dosage of cement, silica fume and SP in ERPC results in a material cost up to 15 times higher than those of the ordinary concrete and high-performance concrete considered (Table 6).

However, the cost per $\mathrm{m}^{3}$ of ERPC should be analyzed in terms of gain of performances. The performance ratios between each concrete and the ordinary concrete were calculated for the compressive strength $R_{C}$, the gas permeability $K_{V}$, the water-accessible porosity $n$ and the chloride diffusion coefficient $D_{e}$ (Table 6). Considering the mechanical properties, the HPC had the best cost/benefits ratio: the ratio between the cost of HPC and OC was about the same that the ratio between their compressive strength. For the ERPC, the cost ratio with OC ranged from 12.7 to 14.7 , whereas their mechanical strength was multiplied only by a factor comprised between 3.0 and 3.8. The real benefits of ERPC appeared on their potential of durability: indeed, the performance ratios between ERPC and OC reached 140 for the intrinsic gas permeability, 13 for the water-accessible porosity and 21 for the chloride diffusion coefficient, far from the durability performance ratios between HPC and OC.

Table 5. Average costs of main components of concrete, excluding transport

\begin{tabular}{|l|c|c|}
\hline Constituents & Cost $(€ /$ ton) & References \\
\hline Cement & 110 & (SESSI 2007) \\
\hline Silica fume & 500 to 2000 & Manufacturer's data (2011) \\
\hline Crushed quartz & 150 & Manufacturer's data (2011) \\
\hline Fine sand for RPC & 80 & Manufacturer's data (2011) \\
\hline Aggregates & 7 & (Bodet 2003) \\
\hline Superplasticizer (SP) & 1640 & Manufacturer's data (2011) \\
\hline
\end{tabular}


Table 6. Comparative data of the cost and performances of concretes (the indicated costs are based on the cost of the concrete constituents and do not take into account the cost of manufacturing, transportation, and implementation of concrete)

\begin{tabular}{|c|c|c|c|c|c|c|}
\hline \multirow{2}{*}{ Concrete } & \multicolumn{2}{|r|}{ Estimated cost } & \multicolumn{4}{|c|}{$\begin{array}{l}\text { Performance ratios as compared } \\
\text { with ordinary concrete (OC) }\end{array}$} \\
\hline & $\left(€ / \mathrm{m}^{3}\right)$ & $\begin{array}{l}\text { Ratio with the cost } \\
\text { of ordinary concrete }\end{array}$ & $\frac{R_{C}}{R_{C}(\mathrm{OC})}$ & $\frac{K_{V}}{K_{V}(\mathrm{OC})}$ & $\frac{n}{n(\mathrm{OC})}$ & $\frac{D_{e}}{D_{e}(\mathrm{OC})}$ \\
\hline $\mathrm{OC}$ & 52 & 1 & 1 & 1 & 1 & 1 \\
\hline $\mathrm{HPC}$ & 90 & 1.7 & 1.8 & 3.6 & 1.3 & 7.2 \\
\hline ERPC_1 & 696 & 13.4 & 3.4 & 60.0 & 13.4 & 17.9 \\
\hline ERPC_2 & 727 & 14.0 & 3.3 & 138.9 & 11.6 & 16.6 \\
\hline RPC_3 & 764 & 14.7 & 3.0 & 87.9 & 10.6 & 13.6 \\
\hline ERPC_4 & 660 & 12.7 & 3.8 & $>140$ & 6.8 & 21.3 \\
\hline ERPC_5 & 669 & 12.9 & 3.7 & $>140$ & 9.1 & 17.4 \\
\hline
\end{tabular}

\section{Conclusions}

This research work focused on the development and the characterization of the fresh, the early-age and the durability performances of five reactive powder concretes (RPC), prepared with various dosages of superplasticizer and a partial replacement of silica fume with crushed quartz. The analysis of the results highlighted the following key points:

- Among the five RPC manufactured, four of them exhibited properties of extrudability. The extrusion tests, conducted at different ram speeds, gave a homogeneous, continuous and visible crack-free extrudate of these concretes;

- The replacement of $25 \%$ of silica fume with crushed quartz showed significant positive effects on the hydration rate, the development of earlyage autogenous shrinkage, the 28-day mechanical performances and the long-term mass transfer properties of the extrudable reactive powder concretes (ERPC);

- The cost/performances ratio analysis of the ERPC underlined that the major advantage of these concretes lies in their exceptional potential of durability rather than in their mechanical strength, when comparing with conventional and high-performance concretes.

This work was conducted to optimize the composition of the ERPC matrix, free of fibers. The study of both the effect of fibers on the behavior of ERPC and the feasibility of extruding tubular pieces will be the next steps of this research work. 


\section{Acknowledgement}

The authors are grateful to Dr. Amor Ben Fraj, for his help in conducting the gas permeability and chloride penetration tests.

\section{Bibliography}

AFPC-AFREM, "Compte-rendu des journées techniques de l'AFPC-AFREM", Toulouse, 1112 décembre 1997 (In French).

Aïtcin P.C., "Cements of yesterday and today: concrete of tomorrow", Cement and Concrete Research, vol. 30, n 9, 2000, p. 1349-1359.

Aïtcin P.C., "Les bétons à haute performance", Note trimestrielle d'information du CETIM (Centre d'Etudes et de Services Technologiques de l'Industrie des Matériaux de Construction), $\mathrm{n}^{\circ} 11,2003$, p. 5-8 (In French).

Aouadja F.Z., Mimoune M., Doustens A., Laquerbe M., “Contribution à l'étude de simulation du procédé d'extrusion - Mise au point d'un nouvel appareil", Materials and Structures, vol. 30, n 9, 1997, p. 561-565 (In French).

Baroghel-Bouny V., Mounanga P., Khelidj A., Loukili A., Rafaï N., “Autogenous deformations of cement pastes - Part II: W/C effects, micro-macro correlations and threshold values", Cement and Concrete Research, vol. 36, n 1, 2006, p.123-136.

Beltzung F., Wittmann F.H., "Early chemical shrinkage due to dissolution and hydration of cement", Materials and Structures, vol. 34, n 5, 2001, p. 279-283.

Blais P.-Y., Couture M., "Precast, prestressed pedestrian bridge - World's first reactive powder concrete structure, PCI Journal, 1999, p. 60-71.

Bodet R., Substitution des granulats alluvionnaires dans l'industrie du béton par les granulats marins, concassés ou recyclés, Rapport de recherche n DDE 27, mai 2003, CERIB (In French).

Bonneau O., Vernet C., Moranville M., Aïtcin P.-C., "Characterization of the granular packing and percolation threshold of reactive powder concrete", Cement and Concrete Research, vol. 30, n 12, 2000, p. 1861-1867.

Bouasker M., Mounanga P., Khelidj A., Coué R., "Free autogenous strain of early-age cement paste: Metrological development and critical analysis", Advances in Cement Research, vol. $20, \mathrm{n}^{\circ} 2,2008$, p. $75-84$.

Cheng Yi H., Feldman R.F., "Hydration reactions in Portland cement-silica fume blends", Cement and Concrete Research, vol. 15, n 4, 1985, p. 585-592.

Cherkaoui K., Courtial M., Dunstetter F., Khelidj A., Mounanga P., de Noirfontaine M.-N., "Early-age volume changes of extrudable reactive powder concrete", Proceedings of ICEM14, 14th International Conference on Experimental Mechanics, 4-9 July 2010, Poitiers (France) 
Courtial M., de Noirfontaine M.N., Dunstetter F., Mounanga P., Cherkaoui K., Khelidj A., "Microstructure d'un Béton de Poudre Réactive Extrudable", Actes des XXIX èmes Rencontres Universitaires de Génie Civil, 29-31 May 2011, Tlemcen (Algeria) (In French).

Cyr M., Lawrence P., Ringot E., "Efficiency of mineral admixtures in mortars: Quantification of the physical and chemical effects of fine admixtures in relation with compressive strength", Cement and Concrete Research, vol. 36, n² 2, 2006, p. 264-277.

Denarié E., Brühwiler E., "Tailored composite UHPFRC-concrete structures”, Proceedings of the 16th European Conference of Fracture Location: Measuring, Monitoring and Modeling Concrete Properties, p. 69-75, 2006, Alexandroupolis (Greece).

Djerbi A., "Influence de l'endommagement mécanique sur la perméabilité au gaz et sur la diffusion des ions chlore des bétons", Thèse de doctorat, Université de Nantes, 2007 (In French)

Djerbi A., Bonnet S., Khelidj A., Baroghel-Bouny V., "Influence of traversing crack on chloride diffusion into concrete", Cement and Concrete Research, vol. 38, n 6, 2008, p. 877-883.

Jensen O.M., Hansen P.F., "A dilatometer for measuring autogenous deformation in hardening Portland cement paste", Materials and Structures, vol. 28, n 7, 1995, p. 406409.

Jiang Z., Sun Z., Wang P., "Autogenous relative humidity change and autogenous shrinkage of high-performance cement pastes", Cement and Concrete Research, vol. 35, n 8, 2005, p. $1539-1545$.

Justnes H., Van Gemert A., Verboven F., Sellevold E.J., "Total and external chemical shrinkage of low W/C ratio cement pastes", Advances in Cement Research, vol. 8, $\mathrm{n}^{\circ} 31$, 1996, p. 121-126.

Kadri E.H., Duval R., Aggoun S., Kenai S., "Silica fume effect on hydration heat and compressive strength of high-performance concrete", ACI Materials Journal, vol. 106, $\mathrm{n}^{\circ} 2,2009$, p. 107-113.

Klinkenberg L.J., "The permeability of porous media to liquids and gases", American Petroleum Institute, Source Drilling and Production Practice, 1941, p. 200-213.

${ }^{a}$ Kuder K.G., Shah S.P., "Rheology of extruded cement-based materials", ACI Materials Journal, vol. 104, n 3, 2007, p. 283-290.

${ }^{\mathrm{b}}$ Kuder K.G., Shah S.P., "Tailoring extruded HPFRCC to be nailable", ACI Materials Journal, vol. 104, $\mathrm{n}^{\circ}$ 5, 2007, p. 526-534.

Langan B.W., Weng K., Ward M.A., "Effect of silica fume and fly ash on heat of hydration of Portland cement", Cement and Concrete Research, vol. 32, n 7, 2002, p. 1045-1051.

Laplante P., Boulay C., "Evolution du coefficient de dilatation thermique du béton en fonction de sa maturité aux tout premiers âges", Materials and Structures, vol. 27, n 10 , 1994, p. 596-605. 
Lee M.-G., Wang Y.-C., Chiu C.-T., "A preliminary study of reactive powder concrete as a new repair material", Construction and Building Materials, vol. 21, n 1, 2007, p. 182 189.

Lilkov V., Dimitrova E., Petrov O.E., "Hydration process of cement containing fly ash and silica fume: the first 24 hours", Cement and Concrete Research, vol. 27, n 4, 1997, p. 577-588.

Liu C.-T., Huang J.-S., "Highly flowable reactive powder mortar as a repair material", Construction and Building Materials, vol. 22, $\mathrm{n}^{\circ}$ 6, 2008, p. 1043-1050.

Loukili A., Khelidj A., Richard P., "Hydration kinetics, change of relative humidity and autogenous shrinkage of ultra-high-strength concrete", Cement and Concrete Research, vol. $29, \mathrm{n}^{\circ} 4,1999$, p. $577-584$.

Mansoutre S., Lequeux N., "Quantitative phase analysis of Portland cements from reactive powder concretes by X-ray powder diffraction", Advances in Cement Research, vol. 8, $\mathrm{n}^{\circ}$ 32, 1996, p. 175-182.

Matte V., Moranville M., "Durability of Reactive Powder Composites: Influence of silica fume on the leaching properties of very low water/binder pastes", Cement and Concrete Composites, vol. 21, $\mathrm{n}^{\circ} 1,1999$, p. 1-9.

Mollah M.Y.A., Adams W.J., Schennach R., Cocke D.L., "A review of cementsuperplasticizer interactions and their models", Advances in Cement Research, vol. 12, $\mathrm{n}^{\circ} 4,2000$, p. $153-161$.

Mounanga P., Khelidj A., Loukili A., Baroghel-Bouny V., "Predicting $\mathrm{Ca}(\mathrm{OH})_{2}$ content and chemical shrinkage of hydrating cement pastes using analytical approach", Cement and Concrete Research, vol. 34, n², 2004, p. 255-265.

${ }^{a}$ Mounanga P., Bouasker M., Pertué A., Perronnet A., Khelidj A., "Early-age autogenous cracking of cementitious matrices: Physico-chemical analysis and micro/macro investigations", Materials and Structures, vol. 44, n 4, 2011, p. 749-772.

${ }^{\mathrm{b}}$ Mounanga P., Khokhar M.I.A., El Hachem R., Loukili A., "Improvement of the early-age reactivity of fly ash and blast furnace slag cementitious systems using limestone filler", Materials and Structures, vol. 44, n², 2011, p.437-453.

Odler I., "Hydration, setting and hardening of Portland cement". In Lea's Chemistry of Cement and Concrete (Hewlett P. C. (ed.)). Elsevier, Oxford, 1998, p. 241-297.

Perrot A., "Conditions d'extrudabilité des matériaux à base cimentaire", Thèse de doctorat, INSA Rennes, 2006 (In French).

Perrot A., Lanos C., Melinge Y., Estellé P., "Mortar physical properties evolution in extrusion flow", Rheologica Acta, vol. 46, n 8, 2007, p. 1065-1073.

Picandet V., Khelidj A., Bastian G., "Effect of axial compressive damage on gas permeability of ordinary and high-performance concrete", Cement and Concrete Research, vol. 31, $\mathrm{n}^{\circ} 11,2001$, p. 1525-1532.

Powers T.C., Brownyard T.L., "Studies of the physical properties of hardened Portland cement paste", Bull. 22, Res. Lab. of Portland Cement Association, Skokie, IL, U.S., 1948 reprinted from Journal of American Concrete Institute. (Proc.), vol. 43, 1947. 
Qian X., Zhou X., Mu B., Li Z., "Fiber alignment and property direction dependency of FRC extrudate", Cement and Concrete Research, vol. 33, n 10, 2003, p. 1575-1581.

Resplendino J., Petitjean J., "Ultra-high-performance concrete: First recommendations and examples of application", Proceedings of the Third International Symposium on High Performance Concrete, Orlando, FL, 19-22 October 2003, 18 p.

Richard P., Cheyrezy M., "Reactive powder concretes with high ductility and 200-800 MPa compressive strength”, ACI Special Publication, vol. 144, 1994, p. 507-518.

Richard P., Cheyrezy M., "Composition of reactive powder concretes", Cement and Concrete Research, vol. 25, n 7, 1995, p. 1501-1511.

Scrivener K.L., Kirkpatrick R.J., "Innovation in use and research on cementitious material", Cement and Concrete Research, vol. 38, $\mathrm{n}^{\circ}$ 2, 2008, p. 128-136.

SESSI, Résultats annuels des enquêtes de branche - F14 : Fabrication de produits céramiques et de matériaux de construction, Rapport du Service des études et des statistiques industrielles, 2007 (In French).

Spinner S., Tefft W.E., "A method for determining mechanical resonance frequencies and for calculating elastic moduli from these frequencies", Proceedings ASTM 61, 1961, p. 12211238 .

Taylor, H. F. W. (ed.) Cement Chemistry, 2nd edn. Academic Press, London, 1990, pp. 199242.

Yazici H., "The effect of curing conditions on compressive strength of ultra high strength concrete with high volume mineral admixtures", Building and Environment, vol. 42, $\mathrm{n}^{\circ} 5$, 2007, p. 2083-2089.

Zanni H., Cheyrezy M., Maret V., Philippot S., Nieto P., "Investigation of hydration and pozzolanic reaction in reactive powder concrete (RPC) using ${ }^{29} \mathrm{Si}$ NMR", Cement and Concrete Research, vol. 26, n 1, 1996, p. 93-100.

Zelić J., Rušić D., Veža D., Krstulović R., "The role of silica fume in the kinetics and mechanisms during the early stage of cement hydration", Cement and Concrete Research, vol. $30, n^{\circ} 10,2000$, p. $1655-1662$. 